\title{
Effect of El Niño and La Niña on abundance of frugivorous and nectarivorous terrestrial birds in three tropical forests
}

\author{
Gilbert Barrantes* \& Luis Sandoval \\ Escuela de Biología, Universidad de Costa Rica, Montes de Oca, San José, Costa Rica; gilbert.barrantes@gmail.com; \\ biosandoval@hotmail.com \\ * Correspondence
}

Received 06-X-2017. Corrected 13-XII-2018. Accepted 17-I-2019.

\begin{abstract}
El Niño and La Niña climatic oscillations have dramatic effects on population dynamics and community structure of different animals. For marine birds, El Niño phenomenon drastically increases their mortality and reduces their reproductive success. In terrestrial ecosystems, the lack of long-term longitudinal data limits our understanding of the impact of El Niño and La Niña on bird populations and communities. We analyzed changes in abundance of frugivorous (large, medium, and small) and nectarivorous birds on three tropical forest types (lowland, premontane and montane) during E1 Niño, La Niña and neutral years using data from 16 Christmas' Bird Counts in Costa Rica. Abundance of large and medium size frugivores increased during La Niña events, and the abundance of nectarivores during El Niño in the lowland forest, but neither of these events affected the abundance of small frugivores. In the montane forest, abundance of all four bird groups increased during El Niño, but decreased during La Niña events. Abundance of large, and small frugivores increased in the premontane forest during La Niña events, but other bird groups were not affected by La Niña. The abundance of small frugivores also increased during El Niño. We hypothesize that changes in abundance of frugivores and nectarivores during La Niña and El Niño events is probably correlated with fluctuations in food resources as it has been reported for other terrestrial tropical ecosystems.
\end{abstract}

Key words: El Niño; La Niña; nectarivorous birds; frugivorous birds; climatic change.

Barrantes, G., \& Sandoval, L. (2019). Effect of El Niño and La Niña on abundance of frugivorous and nectarivorous terrestrial birds in three tropical forests. Revista de Biología Tropical, 67(2) Suplemento, S282-S297.

The evaluation of the changes in patterns of bird abundance is important for our understanding of factors that could affect population dynamics (survival and mortality) and animal communities (changes in species composition) (Holt, 1993; Yodzis, 1993; Brown, 1995). In bird communities, species often adjust the timing of molting, migration and reproduction to fluctuations in food resourses, which in turn respond to predictable, seasonal climatic changes (Stiles, 1985; Loiselle \& Blake, 1991; Worthington, 1996). Unpredictable climatic anomalies such as El Niño Southern Oscillation (hereafter El Niño) and presumably La Niña phenomenon, have a strong impact on survivorship and reproduction in many bird populations, and consequently affect the community structure (Grant \& Grant, 1983; Stiles, 1992; Jaksic \& Laso, 1999). El Niño occurs approximately every 4.1 years (Glynn, 1988), but oscillates between two and ten years (Philander, 1985). El Niño and La Niña represent extremes in sea-surface temperatures, with El 
Niño being above mean temperature and $\mathrm{La}$ Niña below it (Andreoli \& Kayano, 2005).

The impact of El Niño and La Niña on bird populations often varies between taxonomic groups. Seabirds are presumably more strongly affected than land-bird species. For example, rates of survivorship and reproduction of many marine bird species (e.g., Phalacocrorax bougainvilli, Sula variegata, Pelecanus thagus, Nonnopternum harrisi, Diomedea irrorata, and Spenicus mendiculus) that nest in the area of maximum impact of El Niño are drastically reduced, particularly during strong El Niño events (Idyll, 1973; Boersma, 1978; Tovar, Guillen, \& Cabrera, 1987; Rechten, 1985; Hays, 1986; Valle, Cruz, Cruz, Merlen, \& Coulter, 1987; Glynn, 1988). During the strong El Niño events food supply for marine birds (e.g., the sardine Sardinops sagax and the anchovy Engraulis ringens) decrease strikingly, precluding birds to reproduce or greatly increasing mortality, particularly of juveniles (Ashmole, 1971; Hays, 1986; Anderson, 1989).

The effect of El Niño events on terrestrial bird populations in the Neotropics is difficult to evaluate for several reasons. First, occurrence, duration and intensity of El Niño are unpredictable (Cai et al., 2014). Second, the occurrence and intensity of La Niña is even less predictable (Grimm, Ferraz, \& Gomes, 1998). Third, there is a lack of long-term monitoring data needed to evaluate the impact of these unpredictable climatic phenomena on the dynamics of bird populations in tropical forests (Wolfe \& Ralph, 2009). During El Niño events, precipitation in general decreases in the Neotropical region, producing extensive droughts in areas where rains dominate year-round under normal conditions (Nobre \& Shukla, 1996; Andreoli \& Kayano, 2005; Paxton, Cohen, Paxton, Németh, \& Moore, 2014), although precipitation at more localized scales could be higher in some areas during El Niño years (Villalobos \& Retana, 2000). On the contrary, La Niña which sometimes occurs right after El Niño or not at all is often considered the anti-Niño because it has roughly the opposite effect on climatic conditions (Philander,
1985; Brenes \& Bonilla, 2012). Our main objective here is then to test the effect of $\mathrm{El}$ Niño and La Niña events on the abundance of terrestrial bird populations in three different forest types in Costa Rica. We used data from Christmas Bird Counts from 1984 to 2011, the longest data set of bird abundance in Costa Rica. The effect of the El Niño is extremely variable over Central America (Ropelewski \& Halpert, 1987; Enfield \& Mayer, 1997; Sheffield \& Wood, 2008). For instance, Waylen, \& Caviedes (1996) and Giannini, Kushnir, \& Cane (2000) show that El Niño events in Costa Rica produce contrasting climatic conditions between Pacific (decreases rainfall) and Caribbean slopes (increases rainfall). Thereby, we expect contrasting results on bird abundance among forest types since the effect of El Niño could affect differently each forest.

\section{MATERIALS AND METHODS}

Study sites: We selected three localities for which long term monitoring data $(\geq 16$ years) on bird abundance and species composition is available. This data set allows comparisons among multiple events of El Niño, La Niña, and neutral years. The three localities include three forest types: lowland rain forest (La Selva Biological Station, Caribbean slope), premontane forest (Grecia, Pacific slope), and montane forest (Monteverde, continental divide that includes portions of both Caribbean and Pacific slopes). Forest vegetation for La Selva and Monteverde were described by Hartshorn, (1983) and Haber, (2000) respectively. Vegetation in Grecia consists of a matrix of large sugar cane and coffee plantations, urban habitats and large fragments of riparian premontane forest.

Bird abundance data: We obtained bird species abundance from Christmas' Bird Counts (CBC) conducted in each locality under Audubon protocol (National Audubon Society, 2010). CBCs use a standard protocol that consists of counting bird species and abundance inside a circle of $24 \mathrm{~km}$ in diameter 
(452.4 $\mathrm{km}^{2}$ area). In each locality, the circle includes the largest area of most forest types in that locality; the location of the circular sampling area is set prior to the first $\mathrm{CBC}$ and this location is maintained through time. Additionally, CBCs are conducted during a single $24 \mathrm{~h}$ period started at 00:00 $\mathrm{h}$ and finished at 24:00 $\mathrm{h}$ on the same routes year after year, which increases the comparative power of the data over time. The period of time analyzed varied across localities: lowland rain forest from 1985 to 2011, premontane forest from 1984 to 2003, and montane forest from 1994 to 2010. Data on $\mathrm{CBC}$ were obtained from The Organization for Tropical Studies (OTS, 2010) (http://www. ots.ac.cr/cbc_laselva) and National Audubon Society (http://www.christmasbirdcount.org).

For each locality, we selected resident large frugivorous $(>30 \mathrm{~g})$, medium size frugivorous $(20-30 \mathrm{~g})$, small frugivorous $(<20$ $\mathrm{g}$ ), and nectarivorous bird species (Table S1). We selected this subset of species because they fulfilled the following criteria: (1) species are conspicuous reducing their false-positive identification, and (2) species main food resource (fruits and nectar) are seasonal and influenced by rainfall levels that change according to El Niño and La Niña occurrence. We only used species recorded in $50 \%$ or more of the CBC in each locality.

Statistical analyses: We compared bird abundance (e.g. count frequency) of species included in each of the four-bird diet-categories for each of the forest types and three weather events (i.e., El Niño, La Niña, neutral years) using Generalized Linear Models with a Poisson distribution or quasipoisson distribution when residuals were over-dispersed (GLM, library MASS). We used Zero Inflated Models (library glmmADMB) with a negative binomial probability distribution when the number of ceros exceed those expected by a Poisson (or quasipoisson) distribution. With the negative binomial probability distribution, we could accomplish the assumptions of normality of residuals and homoscedasticity. El Niño, La Niña, or neutral years were defined with the Oceanic Niño Index (ONI), obtained from https://ggweather.com/enso/oni.htm. Events are defined by the National Oceanic and Atmospheric Administration (https://www. noaa.gov/) as five consecutive overlapping 3 -month periods with values of the ONI index above the $+0.5^{\circ}$ anomaly for warm (El Niño) events, or below the $-0.5^{\circ}$ anomaly for cold (La Niña) events. For the analyses we included the median value (negative or positive) of the 3-month periods for each year defined as El Niño, La Niña, or neutral. Thus, the statistical models included bird-diet categories, weather events, the co-variable "ONI", which account for the variation in climatic conditions during of El Niño, La Niña, and neutral years, and the total number of person-hours per bird count as another covariate in the analyses (i.e., time) to account for yearly-variation in effort and total distance covered, and species as random factors within the model. All analyses were done using the $\mathrm{R}$ statistical language, version 3.0.1 (R Core Team, 2013).

\section{RESULTS}

The number of El Niño, La Niña, and Neutral years were similar for all three study sites. Lowland rain forest included seven years in each of the three weather categories; the premontane forest included six El Niño and La Niña years, and seven neutral years; and the montane forest included six El Niño years, seven La Niña years, and five neutral years.

Lowland rain forest: We tested the effect of weather events on the abundance of 17 large frugivorous (LF), 27 medium size frugivorous (MF), 36 small frugivorous (SF), and 12 nectarivorous $(\mathrm{Nc})$ bird species in the lowland forest (Table S1). The abundance of large and medium size frugivores increased significantly during La Niña events in comparison to neutral years (Table 1, Fig. 1), and the abundance of Nc during the El Niño events relative to neutral years. Abundance of SF was not affected by La Niña or El Niño events; nor El Niño affected significantly the abundance in any of the three 

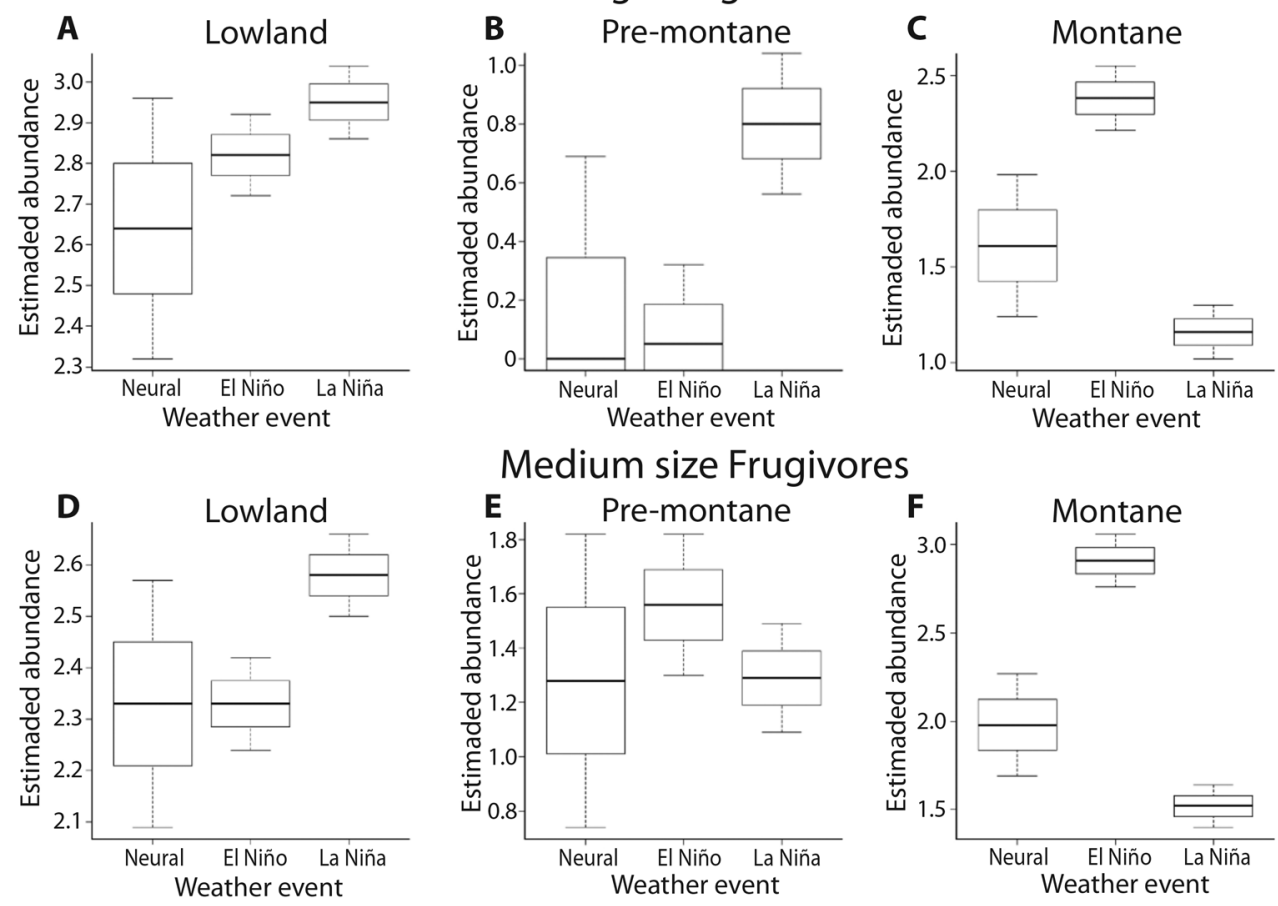

\section{Medium size Frugivores}
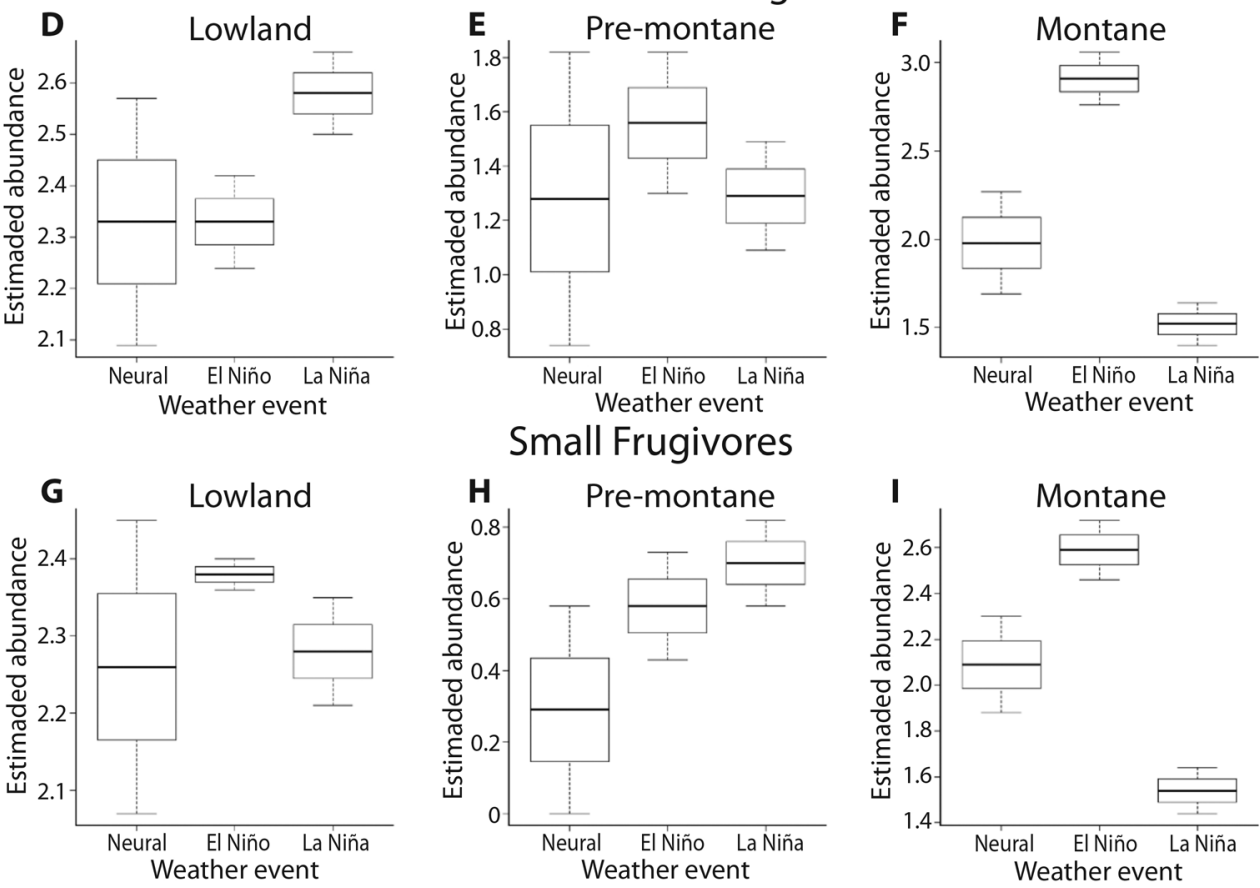

\section{Small Frugivores}
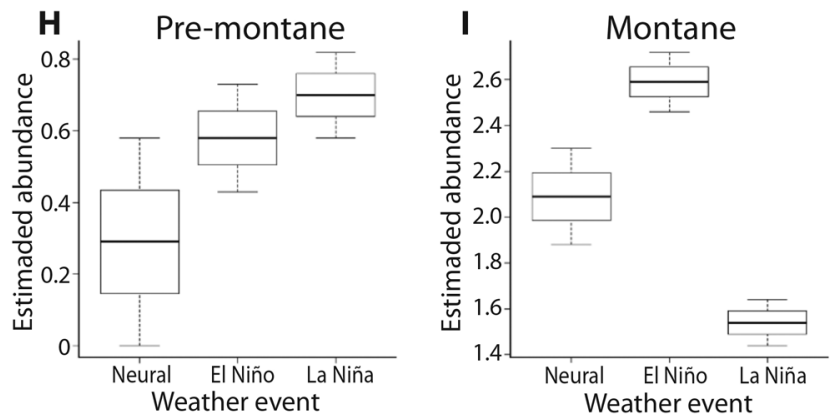

Nectarivores
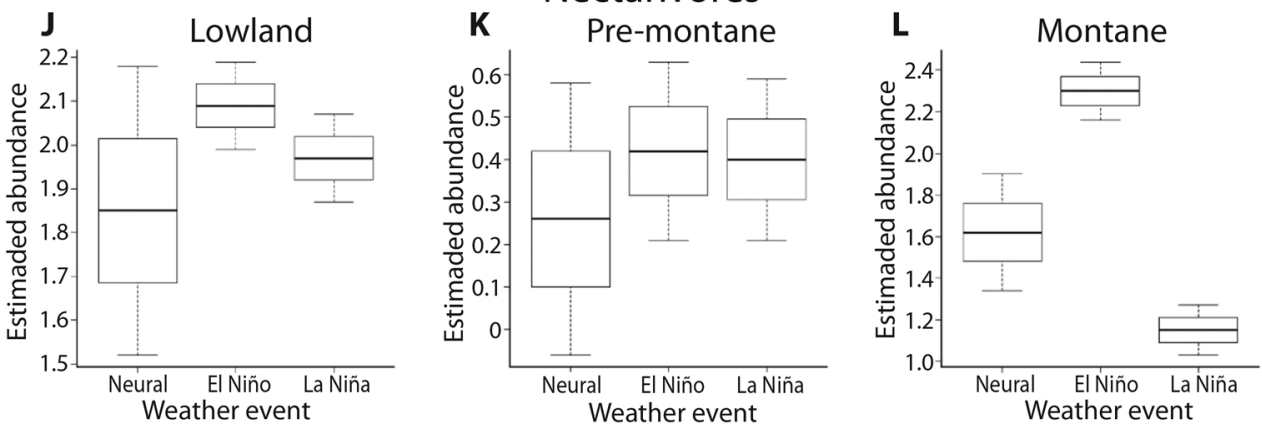

Fig. 1. Mean, standard error, and confidence intervals for three groups frugivorous birds (large, medium size, and small), and nectarivorous birds in three forest types (lowland, pre-montane, and montane). The mean was estimated from the intercept of the statistical models, which directly correlate with the mean values of the variables included in the models. 
TABLE 1

Comparison between climatic events (El Niño, La Niña, and Neutral years) for Large frugivores, Medium size frugivores, Small frugivores, and Nectarivores in three forest types based on Generalized Linear Models with a Poisson probability distribution.

\section{Lowland rain forest}

\begin{tabular}{lcccc}
\multicolumn{1}{c}{ Effect } & Coefficient & SE & T & P \\
Neutral & 2.64 & 0.32 & $8.13(446)$ & 0.0000 \\
Niño - Neutral & 0.18 & 0.10 & $1.81(446)$ & 0.0708 \\
Niña - Neutral & 0.31 & 0.09 & $3.27(446)$ & 0.0011 \\
Niña - Niño & 01.2 & 0.16 & $0.79(446)$ & 0.4274 \\
ONI & 0.05 & 0.05 & $0.92(446)$ & 0.3532 \\
Counting hours & 0.00 & 0.00 & $8.79(446)$ & 0.0000 \\
\hline
\end{tabular}

\section{Medium frugivores}

\begin{tabular}{lcccc}
\multicolumn{1}{c}{ Effect } & Coefficient & SE & T & P \\
Neutral & 2.33 & 0.24 & $9.55(696)$ & $<0.0001$ \\
Niño - Neutral & 0.00 & 0.09 & $0.40(696)$ & 0.9681 \\
Niña - Neutral & 0.25 & 0.08 & $2.99(696)$ & 0.0029 \\
Niña - Niño & 0.25 & 0.14 & $1.75(696)$ & 0.0806 \\
ONI & 0.09 & 0.05 & $1.90(696)$ & 0.0581 \\
Counting hours & 0.00 & 0.00 & $8.25(696)$ & $<0.0001$ \\
\hline
\end{tabular}

\begin{tabular}{|c|c|c|c|c|}
\hline \multicolumn{5}{|c|}{ Small frugivores } \\
\hline Effect & Coefficient & SE & $\mathrm{T}$ & $P$ \\
\hline Neutral & 2.26 & 0.19 & $11.57(896)$ & $<0.0001$ \\
\hline Niño - Neutral & 0.12 & 0.02 & $1.60(896)$ & 0.1089 \\
\hline Niña - Neutral & 0.02 & 0.07 & $0.23(896)$ & 0.7881 \\
\hline Niña - Niño & -0.10 & 0.11 & $-0.85(896)$ & 0.3928 \\
\hline ONI & -0.01 & 0.04 & $-0.19(896)$ & 0.8428 \\
\hline Counting hours & 0.00 & 0.00 & $11.33(896)$ & $<0.0001$ \\
\hline \multicolumn{5}{|c|}{ Nectarivores } \\
\hline Effect & Coefficient & SE & $\mathrm{T}$ & $\mathrm{P}$ \\
\hline Neutral & 1.85 & 0.33 & $5.11(321)$ & $<0.0001$ \\
\hline Niño - Neutral & 0.24 & 0.10 & $2.33(321)$ & 0.0203 \\
\hline Niña - Neutral & 0.12 & 0.10 & $1.19(321)$ & 0.2352 \\
\hline Niña - Niño & -0.12 & 0.16 & $-0.76(321)$ & 0.4491 \\
\hline ONI & 0.00 & 0.06 & $0.08(321)$ & 0.9382 \\
\hline Counting hours & 0.00 & 0.00 & $5.66(321)$ & $<0.0001$ \\
\hline
\end{tabular}

\section{Pre-montane forest}

Large frugivores

\begin{tabular}{lcccc}
\multicolumn{1}{c}{ Effect } & Coefficient & SE & T & P \\
Neutral & 0.00 & 0.69 & $0.00(104)$ & 0.9968 \\
Niño - Neutral & 0.05 & 0.27 & $0.19(104)$ & 0.8485 \\
Niña - Neutral & 0.80 & 0.24 & $3.27(104)$ & 0.0015 \\
Niña - Niño & 0.74 & 0.44 & $1.70(104)$ & 0.0913 \\
ONI & 0.22 & 0.14 & $1.62(104)$ & 0.1069 \\
Counting hours & 0.03 & 0.00 & $6.00(104)$ & $<0.0001$ \\
\hline
\end{tabular}


TABLE 1 (Continued)

Medium frugivores

\begin{tabular}{lcccc}
\multicolumn{1}{c}{ Effect } & Coefficient & SE & Z & P \\
Neutral & 1.28 & 0.54 & $2.40(228)$ & 0.017 \\
Niño - Neutral & 0.28 & 0.26 & $1.10(228)$ & 0.272 \\
Niña - Neutral & 0.01 & 0.20 & $0.07(228)$ & 0.942 \\
Niña - Niño & -0.27 & 0.40 & $-0.67(228)$ & 0.504 \\
ONI & -0.07 & 0.13 & $-0.49(228)$ & 0.623 \\
Counting hours & 0.02 & 0.00 & $4.92(228)$ & $<0.001$ \\
\hline & & Small frugivores & & P \\
Effect & Coefficient & SE & T (339) & 0.3254 \\
Neutral & 0.29 & 0.29 & $0.98(338)$ & 0.0469 \\
Niño - Neutral & 0.29 & 0.15 & $1.99(338)$ & 0.0011 \\
Niña - Neutral & 0.41 & 0.12 & $3.29(338)$ & 0.5462 \\
Niña - Niño & -0.29 & 0.15 & $-1.99(338)$ & 0.1370 \\
ONI & 0.10 & 0.07 & $1.49(338)$ & $<0.0001$ \\
Counting hours & 0.02 & 0.00 & $5.96(338)$ & \\
\hline
\end{tabular}

\begin{tabular}{|c|c|c|c|c|}
\hline \multicolumn{5}{|c|}{ Nectarivores } \\
\hline Effect & Coefficient & SE & $\mathrm{T}$ & $\mathrm{P}$ \\
\hline Neutral & 0.26 & 0.32 & $0.82(266)$ & 0.4147 \\
\hline Niño - Neutral & 0.16 & 0.21 & $0.75(266)$ & 0.4522 \\
\hline Niña - Neutral & 0.14 & 0.19 & $0.72(266)$ & 0.4680 \\
\hline Niña - Niño & -0.02 & 0.35 & $-0.05(266)$ & 0.9611 \\
\hline ONI & 0.13 & 0.11 & $1.21(266)$ & 0.2244 \\
\hline Counting hours & 0.02 & 0.00 & $4.99(266)$ & $<0.0001$ \\
\hline
\end{tabular}

Montane forest

Large frugivores

\begin{tabular}{lcccc}
\multicolumn{1}{c}{ Effect } & Coefficient & SE & T & P \\
Neutral & 1.61 & 0.37 & $4.35(268)$ & $<0.0001$ \\
Niño - Neutral & 0.77 & 0.17 & $4.42(268)$ & $<0.0001$ \\
Niña - Neutral & -0.45 & 0.14 & $-3.20(268)$ & 0.0016 \\
Niña - Niño & -1.23 & 0.27 & $-4.65(268)$ & $<0.0001$ \\
ONI & -0.42 & 0.09 & $-4.39(268)$ & $<0.0001$ \\
Counting hours & 0.00 & 0.00 & $4.22(268)$ & $<0.0001$ \\
\hline
\end{tabular}

\begin{tabular}{lcccc}
\hline \multicolumn{1}{c}{ Effect } & \multicolumn{3}{c}{ Medium frugivores } & \\
Neutral & Coefficient & SE & T & P \\
Niño - Neutral & 1.98 & 0.29 & $6.73(506)$ & $<0.0001$ \\
Niña - Neutral & 0.93 & 0.15 & $5.98(506)$ & $<0.0001$ \\
Niña - Niño & -0.46 & 0.12 & $-3.81(506)$ & 0.0002 \\
ONI & -1.39 & 0.23 & $-6.14(506)$ & $<0.0001$ \\
Counting hours & -0.52 & 0.08 & $-6.15(506)$ & $<0.0001$ \\
\hline
\end{tabular}


TABLE 1 (Continued)

Small frugivores

\begin{tabular}{ccccc} 
Effect & Coefficient & SE & T & P \\
Neutral & 2.09 & 0.21 & $10.06(829)$ & $<0.0001$ \\
Niño - Neutral & 0.50 & 0.13 & $3.77(829)$ & $<0.0001$ \\
Niña - Neutral & -0.55 & 0.10 & $-5.24(829)$ & $<0.0001$ \\
Niña - Niño & -1.05 & 0.13 & $-3.77(829)$ & $<0.0001$ \\
ONI & -0.30 & 0.07 & $-4.18(829)$ & $<0.0001$ \\
Counting hours & 0.00 & 0.00 & $4.69(8.29)$ & $<0.0001$ \\
\hline & & Nectarivores & Z & $<0.0001$ \\
Effect & Coefficient & SE & $5.87(468)$ & $<0.0001$ \\
Neutral & 1.62 & 0.28 & $4.66(468)$ & $<0.0001$ \\
Niño - Neutral & 0.68 & 0.14 & $-4.14(468)$ & $<0.0001$ \\
Niña - Neutral & -0.47 & 0.12 & $-5.57(468)$ & $<0.0001$ \\
Niña - Niño & -1.15 & 0.21 & $-5.35(468)$ & $<0.0001$ \\
ONI & -0.41 & 0.08 & $3.06(468)$ & \\
Counting hours & 0.00 & 0.00 & &
\end{tabular}

The intensity of the climatic event (ONI Index) was included in the model.

The corresponding degrees of freedom are included in parentheses besides the T-values.

The Z-values correspond to the Zero Inflated Models.

groups of frugivores (Table 1). Neither we found significant differences in the abundance of frugivores and nectarivores between La Niña and El Niño events (Table 1). The ONI did not have a significant effect on frugivorous and nectarivorous birds in the lowland rain forest (Table 1).

Pre-montane forest: For the premontane forest, we analyzed the abundance of $6 \mathrm{LF}$, $12 \mathrm{MF}, 19 \mathrm{SF}$, and $15 \mathrm{Nc}$ bird species. In this forest, the abundance of LF and SF increased significantly during La Niña events when compared with neutral years (Table 1, Fig. 1), but it did not affect the abundance of MF nor Nc. The abundance of SF also increased during El Niño, but it did not affect the abundance of other groups. The ONI had no effect on abundance of any of the bird groups (Table 1).

Montane forest: For the montane forest, we analyzed the abundance of $17 \mathrm{LF}, 30 \mathrm{MF}$, $49 \mathrm{SF}$, and $26 \mathrm{Nc}$ bird species. In this forest the abundance of all three groups of frugivores and the nectarivores increased during El Niño events in comparison to neutral years, but decreased for all bird groups during $\mathrm{La}$ Niña events (Table 1, Fig. 1). The abundance of all four groups correlated negatively with ONI index values (Table 1). Thus, the abundance of birds in the montane forests has a strong increment during El Niño events, despite that bird abundance decreased as the index ONI increased.

The total number of person-hours per bird count correlated positively with bird abundance in all cases. However, the ONI index had only a significant effect on bird abundance in the Montane forest.

\section{DISCUSSION}

The variation in the abundance of frugivorous and nectarivorous birds detected in this study could be the result of temporal and spatial changes in the phenology of flowering and fruiting species (food resources) caused by El Niño and La Niña events. The shifting in the pattern of precipitation, intensity of rainfall, and radiation caused by El Niño and La Niña directly affect the periodicity of phenological 
phases, the distribution, and mortality of plants (Wright, Carrasco, Calderón, \& Paton, 1999; Villalobos \& Retana, 2000; Holmgren, Scheffer, Ezcurra, Gutiérrez, \& Mohren, 2001; Jaksic, 2001; McPhaden, Zebiak, \& Glantz, 2006; Chen \& Cane, 2008). For instance, flowering and fruiting of understory plant species correlate with increasing temperature and radiation (Kimura, Yumoto, Kikuzawa, \& Kitayama, 2009). Increasing variation of food resources (Wright et al., 1999) could force birds to change their movement patterns or to move to areas where the effect of these climatic anomalies is milder. Such variation could also increase mortality of birds if food resources decrease drastically (Wolfe \& Ralph, 2009; Boyle, Norris, \& Guglielmo, 2010), and all these factors could affect the abundance of species locally (Jaksic \& Laso, 1999).

The fluctuation in bird abundance across bird groups in this study is similar to that reported for other terrestrial ecosystems in the Neotropics. For instance, in Barro Colorado island (Panama) fruit production greatly increases during El Niño events but decreases drastically when a mild dry season (e.g., the Niña event) follows El Niño, thus increasing mortality of frugivorous mammals (Foster, 1982; Wright et al., 1999). In the Galapagos Islands, reproduction and recruitment of Geospiza fortis significantly increased as a result of high production of seeds during the strong rainy season of El Niño 1982-1983 (Grant, 1986). In Chile, the diversity and density of several groups of landbirds increased during El Niño 1997-1998 (Jaksic \& Laso, 1999). These changes in diversity and density are presumably a direct consequence of increasing rainfall in the region during El Niño years (Jaksic \& Laso, 1999).

The effect of El Niño on climate varies among events and geographical scales. In Chile, total rainfall increases during El Niño but in Barro Colorado Island, rainfall actually decreases during these events, although increases in food resources have in both cases been attributed to El Niño events (Wright et al., 1999; Jaksic, 2001). In Costa Rica, precipitation during the El Niño and La Niña events also varies between slopes and across events (Waylen, Quesada, \& Caviedes, 1994; Waylen, \& Caviedes, 1996; Waylen, Caviedes, Poveda, Mesa, \& Quesada, 1998; Brenes \& Bonilla, 2012). This variation affects differently the abundance of the bird groups in different forests. In the lowland forest abundance of frugivores (large and medium size) increased during La Niña years, but El Niño years did not have a significant effect on frugivores abundance, though abundance of nectarivores increased during these events (Table 1, Fig. 1). The montane forest showed an entirely opposite pattern for frugivores. In this forest, the abundance increased consistently for all frugivorous and nectarivorous birds during $\mathrm{El}$ Niño events, but their abundance decreased during La Niña. It is notable in the montane forest that El Niño has a strong positive effect on bird abundance, but this abundance tends to decrease if intensity of El Niño increases (Table 1). This suggests that there are at least two different processes affecting bird abundance in montane forests. One that likely makes birds to move uphill during El Niño, and another, perhaps less intense, affecting negatively their abundance at high elevation. In the premontane forest these climatic events had little effect on bird abundance. Only abundance of SF increased during La Niña events, but had no effect on LF, MF, and Nc (Table 1, Fig. 1). It is likely that differences in climatic conditions at small geographical scales affects differently plant phenology, and so avian food resources in each forest type, but until we have detailed information on the climatic conditions along the mountain slopes and their effect on bird food resources, the response to fluctuation in frugivores and nectarivores will remain elusive (Williams-Linera \& Meave, 2002).

The changes in abundance during El Niño and La Niña events could be attributed to temporal and spatial fluctuation in food resources, but these climatic events may also affect bird reproduction and survivorship (Wolfe, Ralph, \& Elizondo, 2015). Both climatic events may have drastic negative effects at the level 
of population and community structure. For instance, some populations of Darwin's finches (Geospiza spp.) fail to reproduce during extremely dry years, which usually coincide with La Niña events, and mortality increases up to $85 \%$ during these years and sex ratio skewed toward males (Boag \& Grant, 1981; 1984; Grant \& Grant, 1983; Grant, 1986). These factors delayed the recovery of populations (Boag \& Grant, 1984). Similarly, survivorship of the Long-billed Hermit (Phaetornis longirostris) drastically decreased in a Costa Rican rain forest as a consequence of a flower shortage caused by a severe drought during El Niño event 1972-1973 (Stiles, 1992). Recovery of this population lasted about four years. Bird survival may also depend on the specific habitat features. For instance, in Costa Rica Survivorship of the White-collared Manakin (Manacus candei) was drastically affected by el Niño in disturbed forests but not in near mature forests (Wolfe et al., 2015).

Climate scenario models predict that El Niño events will increase in frequency as global, greenhouse warming increases (Cai et al., 2014). Considering that some populations of terrestrial birds require nearly four years to recover after the impact caused the by El Niño and that the mean period of El Niño occurrence is 4.1 yrs (Glynn, 1988), an increase in frequency of these events would increase the probability of some avian populations to become extinct if they are not capable to recover in a shorter time. We finally highlight the importance of long-term data on bird abundance and phenology of plants to evaluate more precisely the effects of the El Niño and La Niña climatic anomalies on population's dynamics and community structure of tropical birds.

Ethical statement: authors declare that they all agree with this publication and made significant contributions; that there is no conflict of interest of any kind; and that we followed all pertinent ethical and legal procedures and requirements. All financial sources are fully and clearly stated in the acknowledgements section. A signed document has been filed in the journal archives.

\section{ACKNOWLEDGEMENTS}

We thank V. Ruiz-Gutiérrez and three anonymous reviewers for their valuable comments on a previous version of the manuscript and to National Audubon Society and Organization for Tropical Studies for allowing us to use the bird count data. LS was supported during the writing part of this manuscript by scholarships and grants from the Ministerio de Ciencia y Tecnología (MICIT) and the Consejo Nacional para Investigaciones Científicas y Tecnológicas (CONICIT) of Costa Rica, the Government of Ontario and the University of Windsor.

\section{RESUMEN}

El efecto de EI Niño y La Niña sobre la abundancia de aves frugívoras y nectarívoras terrestres en tres bosques tropicales. Las oscilaciones climáticas causadas por el fenómeno de El Niño y La Niña tienen efectos drásticos sobre la dinámica de las poblaciones y la estructura de las comunidades. Para aves marinas, el fenómeno de El Niño incrementa drásticamente su mortalidad y reduce su éxito reproductivo. En ecosistemas terrestres, la falta de datos a largo plazo limita nuestro entendimiento sobre el impacto de El Niño y La Niña sobre la dinámica de las poblaciones y comunidades de aves. Nosotros analizamos los cambios en la abundancia de aves frugívoras (grandes, medianos y pequeños) y nectarívoras en tres tipos de bosque tropical (lluvioso de tierras bajas, premontano y montano) durante los años de El Niño, La Niña, y años neutrales usando datos de al menos 16 conteos de navidad (Christmas' Bird Counts) en Costa Rica. La abundancia de frugívoros grandes y medianos incrementó durante los años de La Niña, y la abundancia de nectarívoros durante el Niño en el bosque lluvioso de tierras bajas, pero ninguno de estos eventos afectó la abundancia de frugívoros pequeños en este bosque. En el bosque montano, la abundancia de los cuatro grupos de aves incrementó durante los años de El Niño, pero disminuyó durante los años de La Niña. La abundancia de frugívoros grandes y pequeños aumentó en el bosque pre-montano durante los años de La Niña; sin embargo, la abundancia de los frugívoros medianos y los nectarívoros no fue afectada por los eventos por La Niña o El Niño. La abundancia de frugívoros pequeños también aumentó durante El Niño en este bosque. Proponemos la hipótesis de que los cambios en la abundancia de las aves frugívoras y nectarívoras reflejan fluctuaciones en 
el recurso alimentario, como ha sido reportado en otros ecosistemas terrestres tropicales.

Palabras clave: El Niño; La Niña; aves nectarívoras; aves frugívoras; cambio climático.

\section{REFERENCES}

Anderson, D. J. (1989). Differential responses of boobies and other seabirds in the Galapagos to the 1986-87 El Niño-Southern Oscillation event. Marine Ecology Progress Series, 52, 209-216.

Andreoli, R. V., \& Kayano, M. T. (2005). ENSO-related rainfall anomalies in South America and associated circulation features during warm and cold pacific decadal oscillation regimes. International Journal of Climatology, 25, 2017-2030.

Ashmole, N. P. (1971). Sea bird ecology and the marine environment. In D. S. Farner, \& J. R. King (Eds.), Avian Biology (pp. 224-286). New York: Academic Press.

Boag, P. T., \& Grant, P. R. (1981). Intense natural selection in a population of Darwin's finches (Geospizinae) in the Galápagos. Science, 214, 82-85.

Boag, P. T., \& Grant, P. R. (1984). Darwin's Finches (Geospiza) on isla Daphne Major, Galapagos: breeding and feeding ecology in a climatically variable environment. Ecological Monograph, 54, 463-489.

Boersma, P. D. (1978). Breeding patterns of Galapagos penguins as an indicator of oceanographic conditions. Science, 200, 1481-1483.

Boyle, W. A., Norris, D. R., \& Guglielmo, C. G. (2010). Storms drive altitudinal migration in a tropical bird. Proceedings of the Royal Society B: Biological Sciences, 277(1693), 2511-2519. DOI: 10.1098/ rspb.2010.0344

Brenes, A., \& Bonilla, A. (2012). La Niña 2010-2012. Estudio de Caso Costa Rica: Global Assessment Report on Disaster Risk Reduction. Colombia: Corporación OSSO.

Brown, J. H. (1995). Macroecology. Il: University of Chicago Press.

Cai, W., Borlace, S., Lengaigne, M., van Rensch, P., Collins, M., Vecchi, G., ... Jin, F. F. (2014). Increasing frequency of extreme El Niño events due to greenhouse warming. Nature Climate Change, 4, 111-116.

Chen, D., \& Cane, M. A. (2008). El Niño prediction and predictability. Journal of Computational Physics, 227, 3625-3640.

Enfield, D. B., \& Mayer, D. A. (1997). Tropical Atlantic sea surface temperature variability and its relation to
El Niño-southern oscillation. Journal of Geophysical Research, 102, 929-945.

Foster, R. B. (1982). Famine on Barro Colorado Island. In E. G. Leigh Jr, Rand, A. S., \& D. M. Windsor (Eds.), Ecology of a Tropical Forest (pp. 201-212). DC: Smithsonian Institution Press.

Giannini, A., Kushnir, Y., \& Cane, M. A. (2000). Interannual variability of Caribbean rainfall, ENSO, and the Atlantic Ocean. Journal of Climate, 13, 297-311.

Glynn, P. W. (1988). El Niño-Southern Oscillation 198283: near shore population, community, and ecosystem responses. Annual Review of Ecology and Systematics, 19, 309-345.

Grant, B. R., \& Grant, P. R. (1983). Fission and fusion in a population of Darwin's finches: an example of the value of studying individuals in ecology. Oikos, 41, 530-547.

Grant, P. R. (1986). Ecology and Evolution of Darwin's Finches. N.J.: Princeton University Press.

Grimm, A. M., Ferraz, S. E. T., \& Gomes, J. (1998). Precipitation anomalies in Southern Brazil associated with El Niño and La Niña events. Journal of Climate, 11, 2863-2880

Haber, W. A. (2000). Plants and vegetation. In N. M. Nadkarni, \& N. T. Wheelwright (Eds.), Monteverde: Ecology and Conservation of a Tropical Cloud Forest (pp. 39-70). Oxford: Oxford University Press.

Hartshorn, G. S. (1983). Plants. In D. H. Janzen (Ed.), Costa Rican Natural History (pp. 118-183). Il: Chicago University Press.

Hays, C. (1986). Effects of the 1982-83 El Niño on Humboldt Penguin colonies in Peru. Biological Conservation, 36, 169-180.

Holt, R. D. (1993). Ecology at the mesoscale: the influence of regional processes on local communities. In R. E. Ricklefs, \& D. Schluter (Eds.), Species Diversity in Ecological Communities. Historical and Geographical Perspectives (pp. 77-88). Chicago: University of Chicago Press.

Holmgren, M., Scheffer, M., Ezcurra, E., Gutiérrez, J. R., \& Mohren, G. M. J. (2001). El Niño effects on the dynamics of terrestrial ecosystems. Trends in Ecology and Evolution, 16, 89-94.

Idyll, C. P. (1973). The anchory crisis. Scientific American, $228,22-29$

Jaksic, F. M., \& Lazo, I. (1999). Response of a bird assemblage in semiarid Chile to the 1997-1998 El Niño. Wilson Bulletin, 111, 527-535. 
Jaksic, F. M. (2001). Ecological effects of El Niño in terrestrial ecosystems of western South America. Ecography, 24, 241-250.

Kimura, K., Yumoto, T., Kikuzawa, K., \& Kitayama, K. (2009). Flowering and fruiting seasonality of eight species of Medinilla (Melastomataceae) in a tropical montane forest of Mount Kinabalu, Borneo. Tropics, $18,35-44$.

Loiselle, B., \& Blake, J. G. (1991). Temporal variation in birds and fruits along an elevational gradient in Costa Rica. Ecology, 72, 180-193.

McPhaden, M. J., Zebiak, S. E., \& Glantz, M. H. (2006). ENSO as an integrating concept in earth science. Science, 314, 1740-1745.

National Audubon Society. (2010). The Christmas bird count historical results. Retrieved from http://www. christmasbirdcount.org

Nobre, P., \& Shukla, J. (1996). Variations of sea surface temperature, wind stress, and rainfall over the tropical Atlantic of South America. Journal of Climate, 9, 2464-2479.

OTS. (2010). Conteos navideños La Selva OET, $1985-$ 2005. Retrieved from http://www.ots.ac.cr/images/ downloads/biological-stations/la-selva/species-lists/ bird-counting/7conteos 852005

Paxton, K. L., Cohen, E. B., Paxton, E. H., Németh, Z., \& Moore, F. R. (2014). El Niño-southern oscillation is linked to decreased energetic condition in long-distance migrants. PLoS ONE, 9, e95383. DOI: 10.1371/ journal.pone.0095383

Philander, S. G. H. (1985.) El Niño and la Niña. Journal of the Atmospheric Sciences, 42, 2652-2662.

R Core Team, (2013). R: A Language and Environment for Statistical Computing. Vienna, Austria: R Foundation for Statistical Computing.

Rechten, C. (1985). The waved albatross in 1983 El Niño leads to complete failure. In G. Robinson, \& E. M. del Pino (Eds.), El Niño in the Galapagos Islands: the 1982-1983 Event (pp. 227-237). Ecuador: Charles Darwin Foundation for the Galapagos Islands.

Ropelewski, C. F., \& Halpert, M. S. (1987). Global and regional scale precipitation associated with the El Niño/southern oscillation. Monthly Weather Review, $115,1606-1626$.

Sheffield, J., \& Wood, E. F. (2008). Projected changes in drought occurrence under future global warming from multi-model, multi-scenario, IPCCAR4 simulations. Climate Dynamics, 31, 79-105.

Stiles, F. G. (1985). Seasonal patterns and coevolution in the hummingbird-flower community of a Costa
Rican subtropical forest. Ornithological Monograph, 36, 757-787.

Stiles, F. G. (1992). Effects of a severe drought on the population of a tropical hummingbird. Ecology, 73, $1375-1390$

Tovar, H., Guillen, V., \& Cabrera, D. (1987). Reproduction and population levels of Peruvian guano birds, 1980 to 1986. Journal of Geophysical Research, 92, 14445-14448.

Valle, C. A., Cruz, F., Cruz, J. B., Merlen, G., \& Coulter, M. C. (1987). The impact of the 1982-83 El NiñoSouthern Oscillation on seabirds in the Galapagos Islands, Ecuador. Journal of Geophysical Research, 92, 14437-14444.

Villalobos, R., \& Retana, J. (2000). Costa Rica: Instituto Metorológico Nacional. In J. W. Jones (Ed.), Comparative Assessment of Agricultural Uses of ENSO-Based Climate Forecasts in Argentina, Costa Rica and Mexico (pp. 49-96). Florida: University of Florida.

Waylen, P. R., Quesada, M. E., \& Caviedes, C. N. (1994). The effects of El Niño-Southern Oscillation on precipitation in San José, Costa Rica. International Journal of Climatoloty, 14, 559-568.

Waylen, P. R., \& Caviedes, C. N. (1996). Interannual variability of monthly precipitation in Costa Rica. Journal of Climate, 9, 2606-2613.

Waylen, P. R., Caviedes, C. N., Poveda, G., Mesa, O., \& Quesada, M. E. (1998). Rainfall distribution and regime in Costa Rica and its response to the El NiñoSouthern Oscillation. Conference of Latin Americanist Geographers, 24, 75-84.

Williams-Linera, G., \& Meave, J. (2002). Patrones fenológicos. In M. R. Guariguata, \& G. H. Kattan (Eds.), Ecología y Conservación de Bosques Tropicales (pp. 407-431). Costa Rica: Editorial Tecnológica de Costa Rica.

Wolfe, J. D., \& Ralph, C. J. (2009). Correlations between El Niño - southern oscillation and changes in Nearctic - Neotropic migrant condition in Central America. Auk, 126, 809-814.

Wolfe, J. D., Ralph, C. J., \& Elizondo, P. (2015). Changes in the apparent survival of a tropical bird in response to the El Niño Southern Oscillation in mature and young forest in Costa Rica. Oecologia, 178, 715-721.

Worthington, A. (1996). Population sizes and breeding rhythms of two species of manakins in relation to food supply. In E. G. Leigh Jr, A. S. Rand, \& D. M. Windsor (Eds), Ecology of a Tropical Forest (pp. 213-225). Washington DC: Smithsonian Institution Press. 
Wright, S. J., Carrasco, C., Calderón, O., \& Paton, S. (1999). The El Niño Southern Oscillation, variable fruit production, and famine in a tropical forest. Eco$\log y 80,1632-1647$.
Yodzis, P. (1993). Environment and trophodiversity. In R. E. Ricklefs, \& D. Schluter (Eds.), Species Diversity in Ecological Communities. Historical and Geographical Perspectives (pp. 26-38). Chicago: University of Chicago Press.

\section{Supporting Information}

TABLE S1

Bird species used in the analysis of effect of El Niño and La Niña in three forests of Costa Rica according to the effects of El Niño and La Niña

\begin{tabular}{|c|c|c|c|c|c|c|}
\hline & \multirow[b]{2}{*}{ English name } & \multirow[b]{2}{*}{ Category } & \multirow{2}{*}{$\begin{array}{l}\text { Size } \\
(\mathrm{cm})\end{array}$} & \multicolumn{3}{|c|}{ Forest type } \\
\hline & & & & $\begin{array}{l}\text { Lowland } \\
\text { rainforest }\end{array}$ & $\begin{array}{c}\text { Premontane } \\
\text { forest }\end{array}$ & $\begin{array}{c}\text { Monatane } \\
\text { forest }\end{array}$ \\
\hline \multicolumn{7}{|l|}{ TINAMIFORMES } \\
\hline \multicolumn{7}{|l|}{ Tinamidae } \\
\hline Nothocercus bonapartei & Highland Tinamou & Large frugivouros & 38 & & & $\mathrm{X}$ \\
\hline Tinamus major & Great Tinamou & Large frugivouros & 43 & $\mathrm{X}$ & & $X$ \\
\hline Crypturellus soui & Little Tinamou & Medium frugivouros & 23 & $\mathrm{X}$ & & \\
\hline Crypturellus boucardi & Slaty-breasted Tinamou & Large frugivouros & 28 & $\mathrm{X}$ & & \\
\hline \multicolumn{7}{|l|}{ GALLIFORMES } \\
\hline \multicolumn{7}{|l|}{ Cracidae } \\
\hline Ortalis cinereiceps & Gray-headed Chachalaca & Large frugivouros & 51 & $\mathrm{X}$ & & $\mathrm{X}$ \\
\hline Penelope purpurascens & Crested Guan & Large frugivouros & 86 & $\mathrm{X}$ & & $\mathrm{X}$ \\
\hline Chamaepetes unicolor & Black Guan & Large frugivouros & 64 & & $\mathrm{X}$ & $X$ \\
\hline Crax rubra & Great Curassow & Large frugivouros & 91 & $\mathrm{X}$ & & \\
\hline \multicolumn{7}{|l|}{ Odontophoridae } \\
\hline Odontophorus leucolaemus & Black-breasted Wood-Quail & Medium frugivouros & 23 & & & $\mathrm{X}$ \\
\hline \multicolumn{7}{|l|}{ COLUMBIFORMES } \\
\hline \multicolumn{7}{|l|}{ Columbidae } \\
\hline Patagioenas cayennensis & Pale-vented Pigeon & Large frugivouros & 30 & $X$ & & \\
\hline Patagioenas speciosa & Scaled Pigeon & Large frugivouros & 32 & $\mathrm{X}$ & & \\
\hline Patagioenas flavirostris & Red-billed Pigeon & Large frugivouros & 30 & & $\mathrm{X}$ & $\mathrm{X}$ \\
\hline Patagioenas fasciata & Band-tailed Pigeon & Large frugivouros & 35 & & $\mathrm{X}$ & $\mathrm{X}$ \\
\hline Patagioenas subvinacea & Ruddy Pigeon & Medium frugivouros & 28 & & $\mathrm{X}$ & $\mathrm{X}$ \\
\hline Patagioenas nigrirostris & Short-billed Pigeon & Medium frugivouros & 26.5 & $X$ & & $X$ \\
\hline Columbina inca & Inca Dove & Medium frugivouros & 20 & & & $\mathrm{X}$ \\
\hline Columbina passerina & Common Ground-Dove & Small frugivorous & 16 & & $\mathrm{X}$ & $\mathrm{X}$ \\
\hline Columbina talpacoti & Ruddy Ground-Dove & Small frugivorous & 16.5 & $\mathrm{X}$ & & \\
\hline Claravis pretiosa & Blue Ground-Dove & Medium frugivouros & 20 & $\mathrm{X}$ & & \\
\hline Leptotila verreauxi & White-tipped Dove & Medium frugivouros & 26 & $\mathrm{X}$ & $\mathrm{X}$ & $\mathrm{X}$ \\
\hline Leptotila cassinii & Gray-chested Dove & Medium frugivouros & 24 & $\mathrm{X}$ & & \\
\hline Geotrygon veraguensis & Olive-backed Quail-Dove & Medium frugivouros & 21.5 & $\mathrm{X}$ & & $\mathrm{X}$ \\
\hline Geotrygon chiriquensis & Chiriqui Quail-Dove & Medium frugivouros & 30 & & & $\mathrm{X}$ \\
\hline Geotrygon lawrencii & Purplish-backed Quail-Dove & Medium frugivouros & 25 & & & $\mathrm{X}$ \\
\hline Geotrygon costaricensis & Buff-fronted Quail-Dove & Medium frugivouros & 28 & & & $\mathrm{X}$ \\
\hline Geotrygon montana & Ruddy Quail-Dove & Medium frugivouros & 23 & $\mathrm{X}$ & & \\
\hline \multicolumn{7}{|l|}{ APODIFORMES } \\
\hline \multicolumn{7}{|l|}{ Trochilidae } \\
\hline Glaucis aeneus & Bronzy Hermit & Nectarivorous & & $X$ & & \\
\hline Threnetes ruckeri & Band-tailed Barbthroat & Nectarivorous & & $\mathrm{X}$ & & \\
\hline
\end{tabular}


TABLE S1 (Continued)

\begin{tabular}{|c|c|c|c|c|c|c|}
\hline & \multirow[b]{2}{*}{ English name } & \multirow[b]{2}{*}{ Category } & \multirow[b]{2}{*}{$\begin{array}{l}\text { Size } \\
(\mathrm{mm})\end{array}$} & \multicolumn{3}{|c|}{ Forest type } \\
\hline & & & & $\begin{array}{l}\text { Lowland } \\
\text { rainforest }\end{array}$ & $\begin{array}{l}\text { Premontane } \\
\text { forest }\end{array}$ & $\begin{array}{c}\text { Monatane } \\
\text { forest }\end{array}$ \\
\hline Phaethornis guy & Green Hermit & Nectarivorous & & & & $\mathrm{X}$ \\
\hline Phaethornis longirostris & Long-billed Hermit & Nectarivorous & & $\mathrm{X}$ & & $\mathrm{X}$ \\
\hline Phaethornis striigularis & Stripe-throated Hermit & Nectarivorous & & $\mathrm{X}$ & & $\mathrm{X}$ \\
\hline Doryfera ludovicae & Green-fronted Lancebill & Nectarivorous & & & & $\mathrm{X}$ \\
\hline Colibri delphinae & Brown Violetear & Nectarivorous & & & & $\mathrm{X}$ \\
\hline Colibri cyanotus & Lesser Violetear & Nectarivorous & & & $\mathrm{X}$ & $\mathrm{X}$ \\
\hline Heliothryx barroti & Purple-crowned Fairy & Nectarivorous & & $\mathrm{X}$ & & $\mathrm{X}$ \\
\hline Anthracothorax prevostii & Green-breasted Mango & Nectarivorous & & $\mathrm{X}$ & $\mathrm{X}$ & $\mathrm{X}$ \\
\hline Heliodoxa jacula & Green-crowned Brilliant & Nectarivorous & & & & $\mathrm{X}$ \\
\hline Panterpe insignis & Fiery-throated Hummingbird & Nectarivorous & & & $X$ & $\mathrm{X}$ \\
\hline Heliomaster constantii & Plain-capped Starthroat & Nectarivorous & & & $\mathrm{X}$ & $X$ \\
\hline Lampornis hemileucus & White-bellied Mountain-gem & Nectarivorous & & & & $\mathrm{X}$ \\
\hline Lampornis calolaemus & Purple-throated Mountain-gem & Nectarivorous & & & $X$ & $\mathrm{X}$ \\
\hline Calliphlox bryantae & Magenta-throated Woodstar & Nectarivorous & & & & $\mathrm{X}$ \\
\hline Selasphorus flammula & Volcano Hummingbird & Nectarivorous & & & $\mathrm{X}$ & \\
\hline Selasphorus scintilla & Scintillant Hummingbird & Nectarivorous & & & $\mathrm{X}$ & $\mathrm{X}$ \\
\hline Chlorostilbon canivetii & Canivet's Emerald & Nectarivorous & & & $\mathrm{X}$ & $\mathrm{X}$ \\
\hline Klais guimeti & Violet-headed Hummingbird & Nectarivorous & & $\mathrm{X}$ & & $\mathrm{X}$ \\
\hline Phaeochroa cuvierii & Scaly-breasted Hummingbird & Nectarivorous & & $\mathrm{X}$ & & \\
\hline Campylopterus hemileucurus & Violet Sabrewing & Nectarivorous & & & $\mathrm{X}$ & $\mathrm{X}$ \\
\hline Eupherusa eximia & Stripe-tailed Hummingbird & Nectarivorous & & & $\mathrm{X}$ & $\mathrm{X}$ \\
\hline Elvira cupreiceps & Coppery-headed Emerald & Nectarivorous & & & & $\mathrm{X}$ \\
\hline Chalyburaurochrysia & Bronze-tailed Plumeleteer & Nectarivorous & & $\mathrm{X}$ & & \\
\hline Thalurania colombica & Crowned Woodnymph & Nectarivorous & & $\mathrm{X}$ & & $\mathrm{X}$ \\
\hline Amazilia amabilis & Blue-chested Hummingbird & Nectarivorous & & $\mathrm{X}$ & & \\
\hline Amazilia saucerrottei & Steely-vented Hummingbird & Nectarivorous & & & $\mathrm{X}$ & $\mathrm{X}$ \\
\hline Amazilia tzacatl & Rufous-tailed Hummingbird & Nectarivorous & & $\mathrm{X}$ & $\mathrm{X}$ & $\mathrm{X}$ \\
\hline Amazilia rutila & Cinnamon Hummingbird & Nectarivorous & & & $\mathrm{X}$ & $\mathrm{X}$ \\
\hline Hylocharis eliciae & Blue-throated Goldentail & Nectarivorous & & & $\mathrm{X}$ & \\
\hline \multicolumn{7}{|l|}{ TROGONIFORMES } \\
\hline \multicolumn{7}{|l|}{ Trogonidae } \\
\hline Trogon clathratus & Lattice-tailed Trogon & Medium frugivouros & 30 & $\mathrm{X}$ & & $\mathrm{X}$ \\
\hline Trogon massena & Slaty-tailed Trogon & Medium frugivouros & 30 & $\mathrm{X}$ & & $\mathrm{X}$ \\
\hline Trogon caligatus & Gartered Trogon & Medium frugivouros & 23 & $\mathrm{X}$ & & $\mathrm{X}$ \\
\hline Trogon rufus & Black-throated Trogon & Medium frugivouros & 23 & $\mathrm{X}$ & & \\
\hline Trogon collaris & Collared Trogon & Medium frugivouros & 25 & & $\mathrm{X}$ & \\
\hline Trogon aurantiiventris & Orange-bellied Trogon & Medium frugivouros & 25 & & & $\mathrm{X}$ \\
\hline Pharomachrus mocinno & Resplendent Quetzal & Large frugivouros & 36 & & $\mathrm{X}$ & $\mathrm{X}$ \\
\hline \multicolumn{7}{|l|}{ PICIFORMES } \\
\hline \multicolumn{7}{|l|}{ Capitonidae } \\
\hline Eubucco bourcierii & Red-headed Barbet & Small frugivorous & 15 & & & $\mathrm{X}$ \\
\hline \multicolumn{7}{|l|}{ Semnornithidae } \\
\hline Semnornis frantzii & Prong-billed Barbet & Small frugivorous & 17 & & & $\mathrm{X}$ \\
\hline \multicolumn{7}{|l|}{ Ramphastidae } \\
\hline Aulacorhynchus prasinus & Emerald Toucanet & Medium frugivouros & 29 & & $\mathrm{X}$ & $\mathrm{X}$ \\
\hline Pteroglossus torquatus & Collared Aracari & Large frugivouros & 41 & $X$ & & $X$ \\
\hline Selenidera spectabilis & Yellow-eared Toucanet & Large frugivouros & 36 & & & $\mathrm{X}$ \\
\hline Ramphastos sulfuratus & Keel-billed Toucan & Large frugivouros & 47 & $\mathrm{X}$ & $X$ & $\mathrm{X}$ \\
\hline Ramphastos ambiguus & Yellow-throated Toucan & Large frugivouros & 56 & $\mathrm{X}$ & & \\
\hline
\end{tabular}


TABLE S1 (Continued)

\begin{tabular}{|c|c|c|c|c|c|c|}
\hline & \multirow[b]{2}{*}{ English name } & \multirow[b]{2}{*}{ Category } & \multirow{2}{*}{$\begin{array}{l}\text { Size } \\
(\mathrm{mm})\end{array}$} & \multicolumn{3}{|c|}{ Forest type } \\
\hline & & & & $\begin{array}{l}\text { Lowland } \\
\text { rainforest }\end{array}$ & $\begin{array}{l}\text { Premontane } \\
\text { forest }\end{array}$ & $\begin{array}{l}\text { Monatane } \\
\text { forest }\end{array}$ \\
\hline \multicolumn{7}{|l|}{ PSITTACIFORMES } \\
\hline \multicolumn{7}{|l|}{ Psittacidae } \\
\hline Eupsittula nana & Olive-throated Parakeet & Medium frugivouros & 23 & $\mathrm{X}$ & & \\
\hline Eupsittula canicularis & Orange-fronted Parakeet & Medium frugivouros & 22.5 & & & $\mathrm{X}$ \\
\hline Ara ambiguus & Great Green Macaw & Large frugivouros & 79 & $X$ & & \\
\hline Psittacara finschi & Crimson-fronted Parakeet & Medium frugivouros & 28 & $\mathrm{X}$ & $\mathrm{X}$ & $\mathrm{X}$ \\
\hline Bolborhynchus lineola & Barred Parakeet & Small frugivorous & 16 & & & $\mathrm{X}$ \\
\hline Brotogeris jugularis & Orange-chinned Parakeet & Small frugivorous & 18 & $\mathrm{X}$ & $X$ & $\mathrm{X}$ \\
\hline Touit costaricensis & Red-fronted Parrotlet & Small frugivorous & 17 & & & $\mathrm{X}$ \\
\hline Pyrilia haematotis & Brown-hooded Parrot & Medium frugivouros & 21 & $\mathrm{X}$ & & $\mathrm{X}$ \\
\hline Pionus senilis & White-crowned Parrot & Medium frugivouros & 24 & $\mathrm{X}$ & $\mathrm{X}$ & $\mathrm{X}$ \\
\hline Amazona albifrons & White-fronted Parrot & Medium frugivouros & 25 & & & $\mathrm{X}$ \\
\hline Amazona autumnalis & Red-lored Parrot & Large frugivouros & 34 & $\mathrm{X}$ & & \\
\hline Amazona farinosa & Mealy Parrot & Large frugivouros & 38 & $X$ & & \\
\hline \multicolumn{7}{|l|}{ PASSERIFORMES } \\
\hline \multicolumn{7}{|l|}{ Tyrannidae } \\
\hline Elaenia flavogaster & Yellow-bellied Elaenia & Small frugivorous & 15 & $\mathrm{X}$ & $\mathrm{X}$ & $\mathrm{X}$ \\
\hline Elaenia frantzii & Mountain Elaenia & Small frugivorous & 15 & & $\mathrm{X}$ & $\mathrm{X}$ \\
\hline Mionectes olivaceus & Olive-striped Flycatcher & Small frugivorous & 13 & & & $\mathrm{X}$ \\
\hline Mionectes oleagineus & Ochre-bellied Flycatcher & Small frugivorous & 12.5 & $\mathrm{X}$ & $\mathrm{X}$ & $\mathrm{X}$ \\
\hline Zimmerius vilissimus & Paltry Tyrannulet & Small frugivorous & 9.5 & $\mathrm{X}$ & & $\mathrm{X}$ \\
\hline Rhynchocyclus brevirostris & Eye-ringed Flatbill & Small frugivorous & 15 & $\mathrm{X}$ & & \\
\hline \multicolumn{7}{|l|}{ Tityridae } \\
\hline Tityra semifasciata & Masked Tityra & Medium frugivouros & 21 & $\mathrm{X}$ & $\mathrm{X}$ & $\mathrm{X}$ \\
\hline Tityra inquisitor & Black-crowned Tityra & Small frugivorous & 18.5 & $\mathrm{X}$ & & \\
\hline Pachyramphus versicolor & Barred Becard & Small frugivorous & 12 & & & $\mathrm{X}$ \\
\hline Pachyramphus cinnamomeus & Cinnamon Becard & Small frugivorous & 14 & $X$ & & $\mathrm{X}$ \\
\hline Pachyramphus polychopterus & White-winged Becard & Small frugivorous & 14.5 & $\mathrm{X}$ & & \\
\hline Pachyramphus aglaiae & Rose-throated Becard & Small frugivorous & 16.5 & & & $\mathrm{X}$ \\
\hline \multicolumn{7}{|l|}{ Cotingidae } \\
\hline Querula purpurata & Purple-throated Fruitcrow & Medium frugivouros & 28 & $\mathrm{X}$ & & \\
\hline Cephalopterus glabricollis & Bare-necked Umbrellabird & Large frugivouros & 41 & $\mathrm{X}$ & & $\mathrm{X}$ \\
\hline Lipaugus unirufus & Rufous Piha & Medium frugivouros & 23 & $\mathrm{X}$ & & \\
\hline Procnias tricarunculatus & Three-wattled Bellbird & Medium frugivouros & 30 & $X$ & & \\
\hline Carpodectes nitidus & Snowy Cotinga & Medium frugivouros & 22.5 & $\mathrm{X}$ & & \\
\hline \multicolumn{7}{|l|}{ Pipridae } \\
\hline Corapipo altera & White-ruffed Manakin & Small frugivorous & 10 & & & $\mathrm{X}$ \\
\hline Chiroxiphia linearis & Long-tailed Manakin & Small frugivorous & 11.5 & & $\mathrm{X}$ & $\mathrm{X}$ \\
\hline Dixiphia pipra & White-crowned Manakin & Small frugivorous & 10 & $X$ & & \\
\hline Ceratopipra mentalis & Red-capped Manakin & Small frugivorous & 10 & $\mathrm{X}$ & & \\
\hline Manacus candei & White-collared Manakin & Small frugivorous & 11 & $X$ & & \\
\hline \multicolumn{7}{|l|}{ Oxyruncidae } \\
\hline Oxyruncus cristatus & Sharpbill & Small frugivorous & 16.5 & & & $\mathrm{X}$ \\
\hline \multicolumn{7}{|l|}{ Vireonidae } \\
\hline Vireo leucophrys & Brown-capped Vireo & Small frugivorous & 12 & & & $\mathrm{X}$ \\
\hline Vireo laniuspulchellus & Green Shrike-Vireo & Small frugivorous & 14 & $X$ & & \\
\hline Cyclarhis gujanensis & Rufous-browed Peppershrike & Small frugivorous & 14 & & & $\mathrm{X}$ \\
\hline
\end{tabular}


TABLE S1 (Continued)

\begin{tabular}{|c|c|c|c|c|c|c|}
\hline & \multirow[b]{2}{*}{ English name } & \multirow[b]{2}{*}{ Category } & \multirow{2}{*}{$\begin{array}{l}\text { Size } \\
(\mathrm{mm})\end{array}$} & \multicolumn{3}{|c|}{ Forest type } \\
\hline & & & & $\begin{array}{l}\text { Lowland } \\
\text { rainforest }\end{array}$ & $\begin{array}{l}\text { Premontane } \\
\text { forest }\end{array}$ & $\begin{array}{l}\text { Monatane } \\
\text { forest }\end{array}$ \\
\hline \multicolumn{7}{|l|}{ Corvidae } \\
\hline Cyanolyca cucullata & Azure-hooded Jay & Medium frugivouros & 29 & & & $\mathrm{X}$ \\
\hline Calocitta formosa & White-throated Magpie-Jay & Large frugivouros & 46 & & & $\mathrm{X}$ \\
\hline Psilorhinus morio & Brown Jay & Large frugivouros & 39 & $\mathrm{X}$ & $\mathrm{X}$ & $\mathrm{X}$ \\
\hline \multicolumn{7}{|l|}{ Turdidae } \\
\hline Myadestes melanops & Black-faced Solitaire & Small frugivorous & 17 & & $\mathrm{X}$ & $\mathrm{X}$ \\
\hline Catharus aurantiirostris & Orange-billed Nightingale-Thrush & Small frugivorous & 16 & & $\mathrm{X}$ & $X$ \\
\hline Catharus fuscater & Slaty-backed Nightingale-Thrush & Small frugivorous & 17 & & & $\mathrm{X}$ \\
\hline Catharus frantzii & Ruddy-capped Nightingale-Thrush & Small frugivorous & 16 & & & $\mathrm{X}$ \\
\hline Catharus mexicanus & Black-headed Nightingale-Thrush & Small frugivorous & 16 & $\mathrm{X}$ & & $\mathrm{X}$ \\
\hline Turdus plebejus & Mountain Thrush & Medium frugivouros & 24 & & $\mathrm{X}$ & $\mathrm{X}$ \\
\hline Turdus obsoletus & Pale-vented Thrush & Medium frugivouros & 23.5 & $\mathrm{X}$ & & $\mathrm{X}$ \\
\hline Turdus grayi & Clay-colored Thrush & Medium frugivouros & 23.5 & $\mathrm{X}$ & $\mathrm{X}$ & $\mathrm{X}$ \\
\hline Turdus assimilis & White-throated Thrush & Medium frugivouros & 22 & & & $\mathrm{X}$ \\
\hline \multicolumn{7}{|l|}{ Ptiliogonatidae } \\
\hline Phainoptila melanoxantha & Black-and-yellow Silky-Flycatcher & Medium frugivouros & 21 & & & $\mathrm{X}$ \\
\hline Ptiliogonys caudatus & Long-tailed Silky-Flycatcher & Medium frugivouros & 24 & & $\mathrm{X}$ & \\
\hline \multicolumn{7}{|l|}{ Fringillidae } \\
\hline Euphonia luteicapilla & Yellow-crowned Euphonia & Small frugivorous & 9.5 & & & $\mathrm{X}$ \\
\hline Euphonia hirundinacea & Yellow-throated Euphonia & Small frugivorous & 11 & & $\mathrm{X}$ & $\mathrm{X}$ \\
\hline Euphonia elegantissima & Elegant Euphonia & Small frugivorous & 11 & & & $\mathrm{X}$ \\
\hline Euphonia gouldi & Olive-backed Euphonia & Small frugivorous & 9.5 & $\mathrm{X}$ & & \\
\hline Euphonia minuta & White-vented Euphonia & Small frugivorous & 9 & $\mathrm{X}$ & & \\
\hline Euphonia anneae & Tawny-capped Euphonia & Small frugivorous & 11 & $\mathrm{X}$ & & $\mathrm{X}$ \\
\hline Chlorophonia callophrys & Golden-browed Chlorophonia & small frugivorous & 13 & & $X$ & $X$ \\
\hline \multicolumn{7}{|l|}{ Passerellidae } \\
\hline Chlorospingus flavopectus & Common Bush-Tanager & Small frugivorous & 13.5 & & $\mathrm{X}$ & $\mathrm{X}$ \\
\hline Chlorospingus pileatus & Sooty-capped Bush-Tanager & Small frugivorous & 13.5 & & $\mathrm{X}$ & $\mathrm{X}$ \\
\hline Chlorospingus canigularis & Ashy-throated Bush-Tanager & Small frugivorous & 13 & & & $X$ \\
\hline \multicolumn{7}{|l|}{ Icteridae } \\
\hline Amblycercus holosericeus & Yellow-billed Cacique & Medium frugivouros & 23 & $\mathrm{X}$ & $\mathrm{X}$ & $\mathrm{X}$ \\
\hline Psarocolius wagleri & Chestnut-headed Oropendola & Large frugivouros & 35 & $\mathrm{X}$ & & $\mathrm{X}$ \\
\hline Psarocolius montezuma & Montezuma Oropendola & Large frugivouros & 50 & $\mathrm{X}$ & $\mathrm{X}$ & $\mathrm{X}$ \\
\hline Cacicus uropygialis & Scarlet-rumped Cacique & Medium frugivouros & 23 & $\mathrm{X}$ & & $\mathrm{X}$ \\
\hline Icterus prosthemelas & Black-cowled Oriole & Small frugivorous & 19 & $X$ & & \\
\hline Molothrus oryzivorus & Giant Cowbird & Large frugivouros & 33 & $X$ & & \\
\hline \multicolumn{7}{|l|}{ Cardinalidae } \\
\hline Piranga flava & Hepatic Tanager & Small frugivorous & 18 & & & $\mathrm{X}$ \\
\hline Piranga bidentata & Flame-colored Tanager & Small frugivorous & 18 & & $\mathrm{X}$ & \\
\hline Habia rubica & Red-crowned Ant-Tanager & Small frugivorous & 18 & & $\mathrm{X}$ & $\mathrm{X}$ \\
\hline Habia fuscicauda & Red-throated Ant-Tanager & Small frugivorous & 19 & $X$ & & \\
\hline Chlorothraupiscarmioli & Carmiol's Tanager & Small frugivorous & 17 & $\mathrm{X}$ & & $\mathrm{X}$ \\
\hline Caryothraustes poliogaster & Black-faced Grosbeak & Small frugivorous & 16.5 & $\mathrm{X}$ & & \\
\hline Passerina caerulea & Blue Grosbeak & Small frugivorous & 16.5 & & $\mathrm{X}$ & \\
\hline \multicolumn{7}{|l|}{ Thraupidae } \\
\hline Thraupis episcopus & Blue-gray Tanager & Small frugivorous & 15 & $X$ & $\mathrm{X}$ & $X$ \\
\hline Thraupis palmarum & Palm Tanager & Small frugivorous & 16 & $\mathrm{X}$ & $\mathrm{X}$ & $\mathrm{X}$ \\
\hline Tangara larvata & Golden-hooded Tanager & Small frugivorous & 13 & $X$ & & $\mathrm{X}$ \\
\hline Tangara guttata & Speckled Tanager & Small frugivorous & 13 & & & $\mathrm{X}$ \\
\hline
\end{tabular}


TABLE S1 (Continued)

\begin{tabular}{|c|c|c|c|c|c|c|}
\hline & \multirow[b]{2}{*}{ English name } & \multirow[b]{2}{*}{ Category } & \multirow{2}{*}{$\begin{array}{l}\text { Size } \\
(\mathrm{mm})\end{array}$} & \multicolumn{3}{|c|}{ Forest type } \\
\hline & & & & $\begin{array}{l}\text { Lowland } \\
\text { rainforest }\end{array}$ & $\begin{array}{l}\text { Premontane } \\
\text { forest }\end{array}$ & $\begin{array}{c}\text { Monatane } \\
\text { forest }\end{array}$ \\
\hline Tangara dowii & Spangle-cheeked Tanager & Small frugivorous & 13 & & & $\mathrm{X}$ \\
\hline Tangara inornata & Plain-colored Tanager & Small frugivorous & 12 & $\mathrm{X}$ & & \\
\hline Tangara gyrola & Bay-headed Tanager & Small frugivorous & 13.5 & & & $\mathrm{X}$ \\
\hline Tangara florida & Emerald Tanager & Small frugivorous & 12 & & & $\mathrm{X}$ \\
\hline Tangara icterocephala & Silver-throated Tanager & Small frugivorous & 13 & & & $\mathrm{X}$ \\
\hline Diglossa plumbea & SlatyFlowerpiercer & Nectarivorous & & & $X$ & $\mathrm{X}$ \\
\hline Chrysothlypis chrysomelas & Black-and-yellow Tanager & Small frugivorous & 12 & $X$ & & $\mathrm{X}$ \\
\hline Chlorophanes spiza & Green Honeycreeper & Small frugivorous & 13 & $X$ & & $X$ \\
\hline Tachyphonus luctuosus & White-shouldered Tanager & Small frugivorous & 14 & $\mathrm{X}$ & & \\
\hline Tachyphonus delattrii & Tawny-crested Tanager & Small frugivorous & 14.5 & $\mathrm{X}$ & & \\
\hline Tachyphonus rufus & White-lined Tanager & Small frugivorous & 17 & $\mathrm{X}$ & & \\
\hline Lanio leucothorax & White-throated Shrike-Tanager & Medium frugivouros & 20 & $X$ & & $\mathrm{X}$ \\
\hline Ramphocelus sanguinolentus & Crimson-collared Tanager & Small frugivorous & 18.5 & $X$ & & $\mathrm{X}$ \\
\hline Ramphocelus passerinii & Passerini's Tanager & Small frugivorous & 16 & $X$ & & $\mathrm{X}$ \\
\hline Cyanerpes lucidus & Shining Honeycreeper & Small frugivorous & 10 & $\mathrm{X}$ & & \\
\hline Cyanerpes cyaneus & Red-legged Honeycreeper & Small frugivorous & 11.5 & $\mathrm{X}$ & $X$ & $\mathrm{X}$ \\
\hline Dacnis venusta & Scarlet-thighed Dacnis & Small frugivorous & 11.5 & & & $\mathrm{X}$ \\
\hline Dacnis cayana & Blue Dacnis & Small frugivorous & 11.5 & $X$ & & \\
\hline Coereba flaveola & Bananaquit & Small frugivorous & 9 & $X$ & & $X$ \\
\hline Saltator atriceps & Black-headed Saltator & Medium frugivouros & 24 & $\mathrm{X}$ & & \\
\hline Saltator maximus & Buff-throated Saltator & Medium frugivouros & 20 & $\mathrm{X}$ & $\mathrm{X}$ & $\mathrm{X}$ \\
\hline Saltator grossus & Slate-colored Grosbeak & Small frugivorous & 19 & $\mathrm{X}$ & & \\
\hline Saltator coerulescens & Grayish Saltator & Medium frugivouros & 20 & $\mathrm{X}$ & $\mathrm{X}$ & $\mathrm{X}$ \\
\hline
\end{tabular}

Category refers to the classification of each species according to guild and body size.

Size where obtained from Stiles and Skutch (1989). 